\title{
Money makes the world go round: Shakespeare, commerce and community
}

\author{
c8 \\ El dinero mueve el mundo: \\ Shakespeare, comercio y comunidad
}

\author{
John Drakakis \\ University of Stirling, Great Britain
}

\begin{abstract}
In early modern England money was of central importance to areas of social life that are in the modern world separate from the study of economics. The demand for liquid capital and the practical problems associated with the devising of a monetary system that was reliable exercised the minds of philosophers, social commentators, and dramatists. The template for discussion was laid down by Aristotle, who perceived financial activity as part of the larger community and its various modes of social interaction. Copernicus wrote a treatise on money, as had Nicholas of Oresme before him. But in the sixteenth century dramatists turned their attention to what we would call "economics" and its impact on social life. Writers such as Thomas Lupton, Christopher Marlowe, Ben Jonson, and Shakespeare all dealt with related issues of material greed, usury, hospitality and friendship and the ways in which they transformed, and were transformed by particular kinds of social and economic practice. These concerns fed into the investigation of different kinds of society, particularly turning their attention to their strengths and weaknesses, and in the case of dramatists providing imaginative accounts of the kinds of life that these innovations produced.
\end{abstract}

KEYWORDS: William Shakespeare; Thomas Lupton; Christopher Marlowe; Ben Jonson; Aristotle; Nicolaus Copernicus; Nicholas of Oresme; Michel de Montaigne; Jacques Derrida; Jean-Joseph Goux; Pierre Bourdieu; Karl Marx; Peter Laslett; Politics; Economics; Friendship; Hospitality; Usury.
En la Inglaterra de principios de la Edad Moderna el dinero era de una importancia central en áreas de la vida social que en el mundo moderno no están incluidas dentro del estudio de la economía. La demanda de capital líquido y los problemas prácticos asociados con la creación de un sistema monetario fiable dieron mucho que pensar a filósofos, comentaristas sociales y dramaturgos. El modelo de discusión lo propuso Aristóteles, quien consideraba la actividad financiera como parte de la comunidad y de sus varios modos de interacción social. Copérnico escribió un tratado sobre el dinero, como ya había hecho Nicolás de Oresme antes que él. Pero en el siglo XVI los dramaturgos se fijaron en lo que hoy llamaríamos "economía" y en su impacto en la vida social. Escritores como Thomas Lupton, Christopher Marlowe, Ben Johnson y Shakespeare trataron asuntos relacionados con la avaricia, la usura, la hospitalidad y la amistad, y las maneras en las que estos elementos transformaron y fueron transformados por diferentes tipos de prácticas sociales y económicas. Estos intereses alimentaron la investigación de diferentes tipos de sociedad, centrándose en particular en sus fortalezas y debilidades, y en el caso de los dramaturgos aportando narraciones muy imaginativas de los tipos de vida que surgieron de estas innovaciones.

PALABRAS CLAVE: William Shakespeare; Thomas Lupton; Christopher Marlowe; Ben Jonson; Aristóteles; Nicolás Copérnico; Nicolás de Oresme, Michel de Montaigne; Jacques Derrida; Jean-Joseph Goux; Pierre Bourdieu; Karl Marx; Peter Laslett; Política; Economía; Amistad; Hospitalidad; Usura. 


\section{The importance of Money}

In an anecdote that Peter Laslett recounts in his book The World We Have Lost - Further Explored (1983) he relays, second-hand, the story of a late seventeenth century weaver, Jean $\mathrm{Cocu}$, his wife and three daughters living in Beauvais in the parish of St. Etienne in 1693. The woman and three children (the youngest 9 years old) were all employed in spinning yarn, and the family consumed some 70 pounds of bread per week. At 0.5 sol per pound the family lived well, but as manufacturing crises increased and the price of bread increased sevenfold, by March 1694 the weaver and two of his daughters had died and only the wife and one daughter remained alive (Laslett 1983,127-28). At the root of the problem was money and the family's failure to generate enough income to buy commodities. We live in a secular world, and many of our economic practices are based on assumptions about the circulation of money that even at the end of the early-modern period, would have horrified theologians and philosophers.

In Aristotle's The Politics, that was published in translation in 1598, some clear distinctions are made between the acquisition of commodities necessary to run a household, and what we would now simply call "profit," and he links the latter to the development of a currency, and the growth of trade. He notes that as exchange becomes more systematic

men become more experienced at discovering where and how the greatest profits might be made out of the exchanges. That is why the technique of acquiring goods is held to be concerned primarily with coin, and to have the function of enabling one to see where a great deal of money may be procured (the technique does after all produce wealth in the form of money): and wealth is often regarded as being a large quantity of coin because coin is what the techniques of acquiring goods and trading are concerned with. (Aristotle 1992, 83)

Aristotle goes on to distinguish between a currency that is used to "procure the necessities of life," and one that is used simply to accumulate wealth, and he gives as an example, the tale of Midas (now translated in the twenty first century into an advertisement for the confectionary "Skittles"):

And it will often happen that a man with wealth in the form of coined money will not have enough to eat: and what a ridiculous 
kind of wealth is that which even in abundance will not save you from dying with hunger! It is like the story told of Midas: because of the inordinate greed of his prayer everything that was set before him was turned to gold. (Aristotle 1992, 83)

He distinguishes between two kinds of "acquisition of goods," the one part of "nature" and linked directly with "household management," and another kind "that is associated with trade, which is not productive of goods in the full sense but only through their exchange" (Aristotle 1992, 84).

In the very next section, Aristotle goes on to define what we might call the "politics" of "household management." Laslett's anecdote concerns a weaver who was preoccupied with the "natural" acquisition of wealth, by generating enough money to feed his family at a time of the significant and prolonged rising of the price of bread. But the other form of acquisition (which includes the profit to be made from "trade" and that "depends upon exchange"

is justly regarded with disapproval since it arises not from nature but from men's gaining from each other. Very much disliked also is the practice of charging interest; and the dislike is fully justified, for the gain arises out of currency itself. Not as a product of that for which currency was provided. Currency was intended to be a means of exchange, whereas interest represents an increase in the currency itself. Hence its name Tokos [offspring] for each animal produces its like, and interest is currency born of currency. And so of all types of business this is the most contrary to nature. (Aristotle 1992, 87)

Implicit in this form of "domestic economy" is movement, the making convenient of the traversing of space that is designed primarily to sustain life, and as Pierre Vilar observes, in historical terms "money proper appeared late in the day, and did so on the periphery of the trading system of the ancient world and not within great empires. Trade created money rather than money trade" (Vilar 1976, 27).

In a modern secular society, the movement of goods and commodities, and the "creation" of markets, along with the economic rhetoric of "growth," is associated with a politics of globalisation and its discontents, but even by the end of the sixteenth century by which time trade had become both international and volatile, physical movement, and the material means (money) by 
which it was made possible, was still required to be seen within a larger metaphysical context. In this connection we may note the cases of two men: Nicholas Oresme (ca.1320-1382), a theologian who became canon of Rouen in November 1362, and dean in March 1364, and who, at the request of Charles V, translated Aristotle's Ethics, Politics and Economics, and who became Bishop of Lisieux in November 1377 (Oresme 1956, x). Oresme also formulated a theory of the earth's diurnal rotation and, according to A.C. Crombie, "in its treatment of the mixture of scientific, philosophical and theological issues involved it foreshadowed the controversial writings of Galileo" (Crombie 1969, 2.89). Oresme also wrote a treatise on money (De Moneta ca.1355). The second is Nicholas Copernicus (1473-1543), the late fifteenth and early sixteenth century theologian and astronomer, who in addition to writing on astronomy, also wrote a series of treatises on the subject of "money." Oresme's De Moneta shows the clear influence of Aristotle, including the history of money, emphasising both its "artificiality" and its instrumentality: "an instrument artificially invented for the easier exchange of natural riches," but also its utility in that it "is very useful to the civil community, and convenient, or rather, necessary, to the business of the state, as Aristotle proves in the fifth book of the Ethics" (Oresme $1956,4-5)$. He then cites a couplet from Ovid's Metamorphoses, Book 1 in which an historical context is provided for the evolution and acquisition of "gold":

Not onely corne and other fruites, for sustenance and for store,

Were now exacted of the Earth: but eft they gan to digge,

And in the bowels of the ground unsaciably to rigge,

For Riches coucht and hidden deepe, in places nere to Hell,

The spurres and stirrers unto vice, and foes to doing well.

Then hurtfull yron came abrode, then came forth yellow golde,

More hurtfull then yron farre, then came forth battle bolde,

That feights with bothe, and shakes his sword in cruell bloody hand. (Ovid 1965, 7)

The context is also a moral context, and it was commonplace by the end of the sixteenth century to locate an ambivalence at the heart of "Nature" that we would now identify as the very beginning of the transition from commodity exchange to the evolution of "capital" (Marx 1981, 3.473-74ff.). In Shakespeare's Romeo and Juliet, for example, Friar Lawrence observes that Nature's gifts are relative 
rather than absolute, depending upon the human use to which they are put:

$\mathrm{O}$, mickle is the powerful grace that lies

In plants, herbs, stones and their true qualities,

For naught so vile that on the earth doth live

But to the earth some special good doth give,

Nor ought so good but, strained from that fair use,

Revolts from true birth, stumbling on abuse.

Virtue itself turns vice being misapplied,

And vice sometimes by action dignified. (Romeo and Juliet 2.3.11-18)

Oresme goes on to discuss the "material" of money, and in particular the practical usefulness of "coins," their value, and who authorises them. He resists the use of "alloy" to make gold coins more robust, concluding that "nor can it honestly be done, nor has it been done in any well-governed community" (Oresme 1956, 8). Moreover, while rulers could authorise the coining of money as the protectors of states, money itself belonged "to the community and to individuals" (Oresme 1956, 11). The treatise goes on to cover questions of the intrinsic value of coins, the consequences of what we would now call "devaluation," "reflation" and "inflation," but all this within a clear moral economy in which, pace Aristotle, "natural" processes should be allowed to yield "interest," but "it is monstrous and unnatural that an unfruitful thing should bear, that a thing specifically sterile, such as money, should be fruit and multiply of itself" (Oresme 1956, 25). What we would now call mechanisms of the "exchange rate" and the profit such exchange might produce, in other words "capital," was regarded as "worse than usury" (Oresme 1956, 27). The point is that any alterations in currency and in economic practice could result in a number of ways in an undue impoverishment of the community through forms of alienation and exclusion. Oresme takes up Aristotle's abiding image of the state as a "body" when he says that:

As, therefore, the body is disordered when the humours flow too freely into one member of it, so that the member is often thus inflamed and overgrown while the others are withered and shrunken and the body's due proportions are destroyed and its life shortened; so also in a commonwealth or kingdom when riches are unduly attracted by one part of it. For a commonwealth or kingdom whose princes, as compared, with their subjects, increase beyond measure in wealth, power and position, is as it were a monster, like 
a man whose head is so large and heavy that the rest of his body is too weak to support it. (Aristotle 1992, 44)

Copernicus begins his discussion of money by enumerating four "scourges" that "debilitate kingdoms, principalities, and republics," and they are: "dissention, mortality, barren soil, and debasement of the currency." He notes that the first three are obvious, but "the fourth, which concerns money, is taken into account by few persons and only the most perspicacious. For it undermines states. Not by a single attack all at once, but gradually and in a certain covert manner" (Copernicus 1985, 176). For Copernicus "money is, as it were, a common measure of values," but devaluation could occur as a result of debasing coinage, and that would lead to the ending both of "imports and foreign trade," and will prevent merchants from buying "foreign merchandise in foreign lands with the same money" (Copernicus 1985, 190-91). He argues that "sound money" benefits "not only the state but also themselves [merchants] and every class of people" (Copernicus 1985, 191). Copernicus's point is that the entire social order and interaction with the wider world through trade and commerce, rests upon "sound money." That soundness depended upon "intrinsic" value where "value" itself was fully represented in the coinage, and the substances from which coins were made. As Marc Shell has pointed out, what began as a direct correlation between "face value (intellectual currency) and substantial value (material currency)" gradually became eroded as the process of symbolisation accelerated (Shell 1982, 1). It would not be difficult to chart the shift from the "just price" of a commodity to the concept of "market value" that would move exchange further away from what was assumed to be a relation of equivalence. But Shell's argument offers a more subtle distinction that depends upon the very process of symbolisation that brought an instrument of exchange, money, directly into contact with the organisation of language itself:

Money, which refers to a system of tropes, is also an "internal" participant in the logical or semiological organisation of language, which itself refers to a system of tropes. Whether or not a writer mentioned money or was aware of its potentially subversive role in his thinking, the new forms of metaphorization or exchanges of meaning that accompanied the new forms of economic symbolisation and production were changing the meaning of meaning. (Shell 1982, 3-4) 
We would not need to look beyond the commercialisation of Higher Education in the Western world for a modern example of this process and its capacity to radically transform discourses, professional practices and lives.

\section{From money to morality}

In The Ethics Aristotle is clear about the link between money and "liberality." Under the headings of "Other Moral Virtues" and "Liberality: the right attitude towards money," he notes that it is "more the mark of the liberal man to give to the right people than to receive from the right people, or not to receive from the wrong people; because virtue consists more in doing good than in receiving it, and more in doing fine actions than in refraining from disgraceful ones." There is no denying the "usefulness" of money, but Aristotle notes that "things that have a use can be used both well and badly" (Aristotle 1977, 143). These will be crucial distinctions, and will extend to the notion of "friendship," whether in the Venice of Shakespeare's The Merchant of Venice and Othello, or in the Greece of Timon of Athens.

The combination of an Aristotelian account of money and human psychology augmented with the Christian parable of "Dives and Lazarus," (St. Luke 16: 19-31) is what informs Thomas Lupton's moral interlude All for Money (1577). The Prologue begins with the quasi-Aristotelian question: "What good gift of God but may be misused?" (Lupton 1969, 421). It proceeds from there to offer a dynamic genealogy of interactive abstractions. The trio of Theology, Science and Art set the scene, followed by a declension beginning with Money, and followed by Adulation, Pleasure, Mischievous Help, Sin, Damnation, and finally, Satan who is attended by the specific sins of Gluttony and Pride. Some of these categories are further subdivided into Learning-With Money, Learning-WithoutMoney and Neither-Money-Nor-Learning. At the root of all this activity is Money who is so busy coping with the acquisitive energy that he provokes, that he is forced to enlist the help of Sin:

I was never so weary since the hour I was born!

There is none at all but do crave me, even and morn.

I never rest, night nor day.

I am ever busy when everyone doth play. 
Few blind matters but I must be at their daying;

If I speak the word it is done without praying.

Since I was here last, I swear by this light,

I have made many a crooked matter straight. (All for Money 810-17)

In his book Symbolic Economies after Marx and Freud (1990), JeanJoseph Goux identifies some of these basic connections historically as features of what he calls "the ancient mode of production" that manifested itself in the Hellenic Age:

The solidarity of money and the deity, which we can logically interpret with the dialectical genesis of social exchanges by which money becomes the universal equivalent of commodities and God the universal equivalent of subjects - with the same value of unification and transcendence attributed to both - will continue to be manifest in the Hellenic age. (Goux 1990, 91)

In a Christian moral economy the accumulation of wealth and the criminality that it generates, the resultant social tensions, the acceleration of international trade, and the renewed emphasis upon the symbolic significance of "money" as a commodity in itself, existed side-by-side, and were beginning to destabilise society at every level. Lupton's moral interlude demonstrates, through a series of conceptually differentiated abstractions, the destructive consequences of the convergence of "tangible forms of writing, aesthetic production, social organisation of space" and also "forms of knowledge and consciousness." It exposes "the economic mode of symbolising which obtains in material exchanges and in relations of production linking social subjects, that is, the mode of exchange in the sense inclusive of interaction" (Goux 1990, 88). We might, perhaps, express Lupton's achievement as an inversion of tradition as "realised morality," of what Pierre Bourdieu identifies from an ethnographical point of view as:

The reconciliation of subjective demand and objective (i.e. collective) necessity which grounds the belief of a whole group in what the group believes, i.e. in the group: a reflexive return to the principles of the operations of objectification, practises and discourses, is prevented by the very reinforcement which these productions continuously draw from a world of objectifications produced in accordance with the same subjective principles. (Bourdieu 1987, 164)

What "Money" disrupts is precisely what holds the subjective and the objective world together, elements and "taxonomies" that are the 
"misrecognizable" representations of "the real divisions of the social order," but that "contribute to the reproduction of that order by producing objectively orchestrated practices adjusted to those divisions" (Bourdieu 1987, 163). In this context the "Dives and Lazarus" parable hinges upon a double refusal of "exchange" expressed here as "charity," and that occludes a constitutive social division, manifest in Dives' initial refusal to offer help to the beggar Lazarus, and secondly by the consequential proscription that prevents Lazarus from offering succour, from his place after death in Abraham's bosom, to Dives languishing in the fires of Hell:

23. And being in hell in torments, when he had lifted up his eyes, he seeth Abraham afarre off, and Lazarus in his bosome:

24. And he cried, and saide, father Abraham, haue mercie on me, and send Lazarus, that he may dip the tip of his finger in water, and coole my tongue, for I am tormented in this flame.

25. But Abraham saide, Sonne, remember that thou in thy life time receivedst thy pleasure, and like wise Lazarus paines, but now he is comforted, and thou art tormented. (Luke 16:19-31 [Bible 1595, 483])

The "orchestrated practice" that Dives violates is a refusal to act charitably in the interests of someone less fortunate than himself. But more than that, it fails to acknowledge that the material world is transitory, and that an adjustment to its earthly inequalities will be made in another life and according to a principle of divine "justice."

Lupton's moral interlude acknowledges this fundamental sense of "divine justice," but focuses more directly on a demystification of those "misrecognizable" elements of the social order that "money" has now replaced. A natural order, predicated upon a recognition of social hierarchy, is replaced by a primum mobile that in purely Aristotelian terms is "sterile." In Marlowe's The Jew of Malta it is "The wind that bloweth all the world besides,|Desire of gold" (3.5.3-4) and it is geographically located in "the Western Ind."

Lupton's play is concerned to uphold a morality under threat, whereas in The Jew of Malta Marlowe advances a "new" psychology that is also an exercise in political theory. While the Jew Barabas is concerned to accumulate wealth, he is initially more subtle in the way in which he links his "authority" to Machiavellian "policy": 
And since by wrong thou got'st authority,

Maintain it bravely by firm policy,

At least unprofitably lose it not:

For he that liveth in authority

And neither gets him friends, nor fills his bags,

Lives like the ass that Aesop speaketh of,

That labours with a load of bread and wine,

And leaves it off to snap at thistle tops. (The Jew of Malta 5.2.35-42)

Lupton's interlude exposes the moral and economic workings of the engine-house of a society substantially given over to the pursuit of mammon. It exposes the dual nature of "money" within a moral economy, but it is critical from a moral and ethical (quasiAristotelian) standpoint of the danger of committing to an object that is derived from "nature" but that can assume an independent identity and has the capacity to pervert nature's purposes. Marlowe's play identifies and isolates a source of wealth generation, Barabas, the Jew, but he also lays bare a political philosophy that claims to be universal, in that its methods affect Jew and Christian alike. Unlike Dives, who will never be lodged in Abraham's bosom, Barabas will violate all social protocols and obligations, including those of his family, to protect his accumulated wealth, while at the same time dismissing the Christian faith in an afterlife. The double irony of the play is that the Christian Ferneze (who is left in control at the end) uses the same Machiavellian practices to undermine Barabas in order to acquire power and authority and to justify his duplicity. Moreover, Marlowe's "characters" are not abstractions, although we can still detect a set of stereotypes beneath the surface of the drama. The exotic setting of the play in Malta, a geographical location at the centre of international trade, represents a "community" embedded in an international politics that manifests itself in the quasi-religious conflict between Christian and Ottoman Turk. But in the conflict between "Damned Christian dogs, and Turkish infidels" (5.5.85-86) it is the demonised "Jew" onto whom the burden of the play's Machiavellian politics is displaced. The fate of Calymath is the consequence of "A Jew's courtesy;|For he that did by treason work our fall|By treason hath delivered thee to us" (5.5.107-10). The abstractions of Lupton find themselves transported in Marlowe and in Shakespeare into a recognisable "reality" in which an "afterlife" is reconfigured as an historical "future." 
One more issue needs to be taken into consideration here, and this is connected at one extreme to the practical question noted by Oresme and Copernicus of maintaining the intrinsic value of currency: the "abuse of counterfeiting, clipping and tampering with money" that "has not stopped to this very day" (Copernicus 1985, 188-89) with its ramifications for trading practice. At the other extreme, quantitative, or "economic exchange value" that was the basis upon which "the sequential logic of value forms could be reconstructed almost axiomatically," as Jean-Joseph Goux puts it, "also provided a scheme for the constitution of qualitative values." In other words, the differential mechanisms whereby economic value was established, could be extended to those areas of "culture" that were not, strictly speaking "economic" (Goux 1990, 3).

One obvious example might be Shakespeare's Troilus and Cressida (ca.1602) where the question of "value" determines the progress of the war between Greece and Troy. In Act 2 scene 2 the Trojan camp debate the "value" of Helen, and Hector asserts that "she is not worth what she doth cost|The holding"; this prompts a question from the high-minded Troilus: "What's aught but as 'tis valued?" (2.2.51-52) Hector challenges Troilus's relativism in the following manner:

But value dwells not in particular will;

It holds his estimate and dignity

As well wherein 'tis precious of itself

As in the prizer. "Tis mad idolatry

To make the service greater than the god;

And the will dotes that is inclinable

To what infectiously itself affects,

Without some image of th'affected merit. (Troilus and Cressida 2.2.53-60)

Paris, the abductor of Helen wishes to transform the act of abduction by revaluing his act: "I would have the soil of her fair rape | Wiped off in honourable keeping her" (2.2.148-49). Hector, for his part, views Paris's "reasons" as "the hot passion of distempered blood" (169), and proceeds to invoke "a law in each well-ordered nation | To curb those raging appetites that are|Most disobedient and refractory" (2.2.180-82). In the scene immediately following a third valuation of the war is proposed, this time by the scabrous Thersites: 
After this, the vengeance on the whole camp! Or rather, the Neapolitan bone-ache! For that, methinks, is the curse dependent on those that war for a placket. (Troilus and Cressida 2.3.16-19)

The persistent "valuation"/devaluation/revaluation of Helen reduces everything to the contingent practices of an a-historic present embedded at the heart of an "historic" event. To this extent, the gradual emptying of all value in the breaking of vows, leading to the discrepancy between referent and object, renders meaning itself ineffectual, with the result that at the level of form the play can have no teleological objective, or indeed, no "ending." At one extreme quasi-monetary worth, or Helen as "commodity," and at the other the abstract values of "chivalry," with all the gradations between, culminates in the venal and venereal perspective of Pandarus, the trader in human pulchritude whose only bequest to his audience is "diseases."

\section{Shakespeare's Venetian Plays}

The distance from Thomas Lupton's All For Money to Shakespeare's two Venetian plays is substantial. Venice is not an abstraction but a fully functioning republic, noted for what we would now call its "multiculturalism." It was also noted for its mercantile activity, whose complexity is outlined from an "English" perspective in The Merchant of Venice (1597), and for its controversial acceptance of "strangers," that is also the subject of Othello (1604). I have suggested elsewhere that these plays offer a "reading" of Venice rather than a realist representation of its institutions. Indeed, if you will permit me the vanity of quoting myself, I have argued that the ethnic variety of Venice, its comparative economic freedoms, and its alleged sexual permissiveness, "entered the Elizabethan (and early Jacobean) popular imagination and were interpreted according to the demands of an ideology struggling to contain its own social, political and economic contradictions" (Drakakis 2010,6). The anchoring anxiety that lies behind both plays derives from the problems emanating from money as a means of exchange, but also as a signifier of embryonic capital, and embedded in a series of social practices that involve questions of identity, institutions such as marriage, and issues of power, authority and legitimacy that are central to the ways in which a community defines itself. The "reality" of Venice has been the subject of comments from historians, who have noted that by the 
end of the sixteenth century its international status as a centre of Mediterranean trade was under considerable threat and during the first three decades of the seventeenth century it declined (Wallerstein 1974, 215-21). But possibly in the wake of the performance of Shakespeare's The Merchant of Venice in 1597, and its subsequent appearance in print in 1600, Lewis Lewkenor's translation of Gasparo Contarini's The Commonwealth and Government of Venice (1599), provided considerable information on the workings of a successful "republic," and in particular noted its reception of "strangers." If Marlowe's The Jew of Malta could project the Machiavellian underbelly of economic, and political activity onto the figure of the Jew, then Shakespeare, in dialogue with Marlowe could increase the complexity of the relationship between an "outsider" such as Shylock, and a Christian merchant such as Antonio, both of whom are embedded antagonistically in a community that emphasised values very different from those of Sir Thomas Smith's De Republica Anglorum (1572), but which shared in some measure what Jean-Joseph Goux, in a much larger context, would call the "paterialist" values that Shakespeare ascribes to the Venice of both plays. We might perhaps dwell on Goux's definition for a moment, since it may help us to understand a little more clearly, these plays' paternalism, and their sexual content, as well as their dramatic form. Goux returns to Aristotle, and to the claim that "in Aristotle the opposition between form and matter is of sexual extraction," and that both Plato and Aristotle aligned themselves "with an enduring metaphorical archaeology" that operated in the following way:

If (paternal) form is invariant, (maternal) matter is the changing and relative receptacle that possesses no determinacy or consistency apart from the imprint of this ideal form. When value, or the idea, unfurls its possibilities in the hegemony of the general equivalent, not only the possibilities of idealism but also those of paterialism are deployed - even if the latter becomes increasingly abstract and difficult to discern. (Goux 1990, 213-17)

The difficulties are multiplied when "money" is separated from its intrinsic (and "idealistic") value, and threatens to become a freefloating signifier, that both substitutes for the object of exchange, and assumes a generating power of its own, and that we are familiar with under the name of "capital." At the centre of this transformation is the practice of usury that denotes a quasicapitalistic form of economic exchange, that has the capacity to 
alienate and, from a moral perspective, to demonise its agents. Like the Moor, no matter how integrated or how necessary, the Jew may appear to be, he will always return to type in a paterialist world that desperately clings on to its own self-conception and the philosophical idealism that underpins its economic practices. Both "outsiders" are under-represented in reality in Elizabethan and early Jacobean England, but both are nonetheless the object of considerable social anxiety.

\section{Fathers and children}

In both plays the problems crystallise around "fathers," who are the nominal markers of social authority, and (mainly) "daughters." In The Merchant of Venice the Lord Bassanio has "disabled" his estate "By something showing a more swelling port | Than my faint means would grant continuance" (1.1.124-25). His solution is to replenish his coffers by marriage, and the object of his quest is Portia, "a lady richly left" but who is also "fair and fairer than that word, $\mid$ Of wondrous virtues" (1.1.161-62). Antonio, his "merchant" mentor and surrogate father, is asked to finance the venture, but because he has no available liquid capital, and because he is actively invested in a series of trading projects of his own, he approaches a "usurer." This "borrowing of money" as though it were a commodity in itself, is the beginning of the problem. Portia, for her part, has a dead father, but one who exercises power over her from beyond the grave. But the usurer himself is also a "father," and of an unruly daughter who eventually elopes with the Christian Lorenzo. There is one other parent-child relationship that we are allowed to glimpse fleetingly in the play, and that is the Lancelet / Giobbe relationship, where the suffering father seeks to ensure his son's future livelihood, within a traditional domestic economy of the household, and the son, reciprocally, is in a position to alleviate the father's tribulations; Lancelet also moves, like Jessica, Shylock's daughter, from one "group" to another. The fleeting reference to the tribulations of the Old Testament Job in this truncated comic sup-plot hints generally at the promise of the "son" but takes the issue no further.

The "form" that the drama as a whole takes is that of comedy, in which the "power" of patriarchy is brought into alignment with the requirements of a younger generation, as a means of guaranteeing 
the future of society. Bassanio overcomes the test that Portia's dead father prescribes; her waiting-woman Nerissa imitates her mistress and marries Gratiano; and Antonio is finally united with his wealth, but not before he is brought almost to the point of death as a result of a "bond" he has entered into with Shylock who also has a "family." The "usurer's family is distinguished by its unruliness; his daughter Jessica elopes with his money, but her actions are legitimised by the enforced conversion of her father to Christianity, and Lancelet his servant "escapes" from one household to another.

The play's teleological thrust is to align mercantile success with patriarchal authority, while at the same time restoring the process of exchange to its place in a traditional hierarchy that minimises its threat to the community. But the presence of the usurer opens Pandora's box, even though he is represented in traditional terms as a "necessary evil." In this context, Venice is both a locus of anxiety, whose republican freedoms can be aesthetically crafted to produce a series of "solutions" to social problems that had already begun to surface in economic practices in England. The threats in the play come from two directions: firstly, the economic straits in which Bassanio finds himself generates a desire that is presented as being both economic and sexual; this too leads to a refinement in which he and Antonio share a homosocial relationship that is an extension of patriarchy. In this context the institution of marriage is both a guarantee of the supply of money and of progeny, thereby satisfying the Aristotelian proscription that distinguished between the "sterility" of money, and the virility and vitality of human generation. Portia is initially powerless and must submit to "the will of a dead father" (1.2.24), although once having fulfilled his demands, and when she is later disguised as the lawyer Balthazar, she assumes a power that allows her to expose masculine inconstancy. Thus even within the domestic arena of sexual politics there remains a tension between "romantic idealism" on the one hand, and the materiality of "money" on the other. At the end of the play Antonio's store of wealth is replenished, almost by divine intervention, and he will, presumably, continue to supply the needs of his "friend."

The case of Shylock and Jessica, however, is very different. She and Lancelet regard her father's clearly puritanical household as "Hell," and she plans to elope with Lorenzo. This flagrant violation 
should give us pause for thought, and in the later play Othello it is even more serious. But like Portia, Jessica is empowered by her disguise, and engages in an act that challenges the foundation of patriarchal authority and the source of "meaning" itself. Who chooses the correct casket in the game that Portia's father devises for potential suitors, chooses his meaning. Jessica robs her father of "meaning," and this transforms his "merry bond" with Antonio, that was designed to exhibit "friendship" into something that is potentially deadly, and that reinforces the separation between Jew and Christian in Venice. If Antonio is, indeed, a "tainted wether of the flock" then the nature of that taint must surely, lie in his willingness to enter into a usurious relationship that of its very nature threatens to undermine the fabric of community. His is a mercantilism that exists on the cusp of a transformation from exchange value to the emergence of money as "capital."

No matter what Shylock does, he is pulled back into the orbit of Christian meaning. In his initial encounter with Antonio and Bassanio he seeks to make his "meaning" clear: "My meaning in saying he (Antonio) is a good man is to have you understand me that he is sufficient, yet his means are in supposition" (1.3.14-16). Here "meaning" is reduced to "means," to monetary means, and later what will be at issue will be the "meaning" of the bond itself. The circulation of meaning, its susceptibility to multiple interpretations, is not unlike the circulation of money, and the problem that arises when, like language, it can circulates freely as a signifier of itself in a community still committed to the anchoring of meaning in a "paterial" discourse. The "blood" of youth, is brought into alignment with the free circulation of money, and both are regarded as dangers requiring the submission to legal and moral constraint. This not only requires the law to win out against the usurer, but it also requires conversion to Christian morality, an act that produces discomfort in the psyche of the "stranger" who hitherto admits to having only "imitated" Christian behaviour. Unusually in Shakespeare, this conversion also serves to legitimise what we might otherwise think is the anarchic behaviour of his daughter. That the play seems to retain some sympathy for the scapegoat here, Shylock, the "real" "tainted wether of the flock," challenges the claim that Venice is hospitable to "strangers," and that by implication, a republic, that ostensibly thrives on commercial activities that are deeply suspect, is not the democracy that it claims 
to be. Indeed, in the play it is "money" that poses a threat to "friendship" as Antonio puts it: "when did friendship take |A breed of barren metal of his friend?" (1.3.128-29). Shylock responds, "Why, look you, how you storm. |I would be friends with you and have your love" (1.3.133-34). I want to return to the issue of "friendship" when I consider Timon of Athens.

Alongside the question of the "sterility" of money, the question of miscegenation in The Merchant of Venice is caught up in a much larger mythological discourse surrounding the figure of the "Jew." In Othello parts of the earlier play are re-worked to form a tragedy, where the emphasis is upon the extent to which Venice is "hospitable" to the figure of the "stranger" upon whom it relies for its defence against "the Turk." If in the earlier play, money, and the processes of its circulation in Venice is the problem, in the later play it is the paterial authority of Venice that depends upon "strangers" to protect it against anarchy that is now under scrutiny.

A minor figure in the earlier play, Morocco, becomes the tragic protagonist in the later play, except that this time the role of "villain" and "hero" are ultimately folded into the one dramatis persona. Whereas in earlier Shakespeare comedies elopement is a strategy designed simply to circumvent paternal authority which is shown to be at odds with youthful desire, here Desdemona's "elopement" with Othello - about whose actual circumstances we are never clear - exposes a much deeper division within Venetian society. In what some critics have labelled a "domestic" tragedy, the central relationship that effectively destroys Brabantio's "family" turns out to have its roots in a community that breeds resentment and paranoia, and that leads ultimately to a perverse alignment of "otherness" with the ideal values of the social order itself. In the earlier play the villain is interpellated as a "satanic" figure, and is made to relive subjectively the effects of the "fall" and redemption; in the later play two morally opposed forces play out the drama in the psyche of the tragic hero, faced with defending the very values that his own alter-ego strives to undermine. This is not a protobourgeois tragedy, but a tragedy in the Aristotelian sense, in which the artificially constructed domestic problems of the protagonist are made to impinge directly on his role as defender of Venetian values. The defence takes place on the geographical frontier of Venice's domain in Cyprus, on the border between "Christian" and "Turk," 
the two internalised facets of Venetian subjectivity that are combined in the figure of Othello himself. What in the earlier play is represented as a "disquiet" that is felt initially by Antonio, and that is subsequently bequeathed to the converted Shylock, is worked out more fully, and with deadly effect, in the psychology of a protagonist who is both "noble Moor" and potentially a "blacker devil." If money and commerce make of Antonio and Shylock split subjects, then that process is exacerbated in the later play, to the point where it culminates in an extraordinary suicide that depicts a protagonist alienated from himself.

We would need to go to Ben Jonson's Volpone (1605) to explore the satirical implications of the practices of fraudulent acquisition in Venice. Here, in Othello we, as audience occupy the kind of superior position that we might identify as satirical, except that the discourses of stereotype (the denigration of the Moor as animalistic outsider, and the depiction of the Venetian "housewife") are subjected to a serious scrutiny in which the proliferation of certain meanings are shown, in their alarming volatility, to have devastating consequences. The villainous "white devil" Iago, who is himself both "ensign" and "sign," invites Othello to "read" his wife's and Cassio's behaviour, and directs him to certain conclusions that we know to be false. We should be careful not to displace the threat posed by Iago onto an assumed "naivete" of the protagonist. We see how deadly Iago's method is early in the play in his manipulation of Brabantio and its consequences, and his narrative is plausible precisely because we are never told about the father's part in fostering the relationship between his daughter and Othello. All we know is that Iago's insinuations awaken a deep prejudice in this representative of Venetian law that is later transferred to, and inherited by, his son-inlaw. In what James 1 called "this artificial town" beneath its republican veneer, there is something diseased and fundamentally destructive that eats at its fabric of law and exchange from within, and that is initially projected onto its external enemies.

Shakespeare's critical treatment of Venice in these two plays is an "English" response to a particular kind of community whose imminent decay is inscribed in the very fabric of its practices of exchange and defence. Of course, there are issues that are reflected in Elizabethan and Jacobean anxieties about the complex ways in which new economic practices threatened to undermine the very 
fabric of community itself. If, as Benedict Anderson famously observed, the identity of a community is inscribed in its language, then the threat to meaning that money as an emergent free-floating signifier posed to the process of making meaning could not but involve those institutions upon which the values of the community rested.

\section{Timon of Athens}

The Merchant of Venice and Othello provide a comic and a tragic gloss on some of these issues. But it is to Timon of Athens (1605-1608) that we now need to turn to see how corrosive the process of material acquisition can become, when the values of the protagonist are clearly out of synchronisation with the corrupt society in which he finds himself. Perhaps we should think of Timon as a "Greek" play, with its action located in a particular kind of democracy some of whose values Elizabethans and early Jacobeans shared. As in the case of the Roman plays that select particular tracts of Ancient Roman history as occasion demands, so in the case of Timon, the focus is upon a particular kind of exploitative society dominated by an amoral acquisitive energy. My concern here is not with the vexed question of authorship, or particularly with the possibility that Timon is an untidy and unfinished play. Rather I want to place it within the context of the early seventeenth century preoccupation with "wealth" and its social ramifications. The Arden 3 editors, Anthony Dawson and Gretchen Minton who see the play as a collaborative effort of Shakespeare (as the senior partner) and Thomas Middleton (as the junior partner), invoke Aristotle's The Politics as part of an argument that focuses on "the intricate network of money-getting, one that...is inextricably linked to the issue of economic reproduction" (Dawson and Minton 2008, 80). The play's "sources" are various, stretching back to Lucian's "moral interlude" Timon the Misanthrope, and including, Plutarch's Lives, Painter's Palace of Pleasure (1584), and possibly the anonymous play Timon (ca.1601). If we take these, along with Aristophanes' play Wealth, and with moral interludes such as All for Money (1577), and the plethora of usury tracts that appeared between 1572 and 1605, we have an extended historical context both for the play and for the widespread anxieties surrounding the subject of "money" at this time. Much of these narratives focus upon the misanthropic Timon, that Painter dates 
back to Plato and Aristophanes, when he remarks on "his marveylous nature, because hee was a man but by shape onely, in qualities hee was the capitall enemie of mankinde, which he confessed franckely utterly to abhorre and hate" (Bullough 1977, 6.293). It is Timon's "anti-social" and anti-communal attitude that attracted attention, leading to a form of "beastial" behaviour consequent upon his fall from prosperity into adversity. In Shakespeare's play, that fall is attributed to a specific cause, that lays open to question the connection between "wealth," "friendship" and community in the play.

\section{Friendship}

In book 8 of The Ethics Aristotle notes that "friendship is based on community" and each community is bound together by "some kind of justice and also some friendly feeling" (Aristotle 1977, 273; Montaigne 1965, 2.198). Earlier he dismisses "friendship" based on "utility" where the original ground for association disappears when the benefit derived from it ceases to exist (Aristotle 1977, 261-62). Reading Aristotle, in his The Politics of Friendship (1997), Derrida notes that:

There is no democracy without respect for irreducible singularity or alterity, but there is no democracy without the "community of friends"...without the calculation of majorities, without identifiable, stabilizable, representable subjects, all equal. Tragically irreconcilable and forever wounding. The wound itself opens with the necessity of having to count one's friends, to count the others, in the economy of one's own, there where every other is altogether other. (Derrida 1997, 22)

The Athens of Timon is a thoroughly corrupt Jacobean polity in which we see, to quote Montaigne, "all those amities which are forged and nourished by voluptuousnesse or profit, publicke or private need, are thereby so much the lesse faire and generous, and so much the lesse true amities, in that they intermeddle other causes, scope, and fruit with friendship, than it selfe alone" (Montaigne 1965, 2.196-97). The opening exchange between the Painter, the Poet and the Merchant encapsulates the hypocrisy of a community that invests heavily in the vicissitudes of "Fortune." Both the Poet and the Painter can flaunt their public "moral" representations of the precariousness of Fortune, while at the same time fabricating a 
"friendship" whose source of wealth is likely to fall victim to the very force against whom they inveigh. Painter, Poet and Merchant inhabit a paradoxical universe in which poetry, painting and diamonds, are deployed as investments, used initially as commodities, but also as means of extracting surplus value from their owners' "friendship" with Timon. Whereas most versions of the Timon story castigate him for his imprudent liberality, Shakespeare embeds his generosity in a community that is obsessed with the accumulation of wealth. After an engagement with the misanthropic Apemantus who takes the view that "The strain of man's bred out into baboon and monkey" (1.1.256-57), the Second Lord makes clear how surplus value is produced from Timon's bounty:

He pours it out; Plutus, the god of gold,

Is but his steward: no meed but he repays

Sevenfold above itself, no gift to him

But breeds the giver a return exceeding

All use of quittance. (Timon of Athens 1.1.283-87)

Indeed, everyone seeks to extract surplus value from their "friendship" with Timon, and as a consequence, their friendship with him and with each other is superficial (Aristotle 1977, 269). Initially Timon aims to be on intimate terms with everybody, and he eschews ceremony as being an unnecessary accoutrement of "goodness":

Ceremony was but devised at first

To set a gloss on faint deeds, hollow welcomes,

Recanting goodness, sorry ere 'tis shown.

But where there is true friendship there needs none. (Timon of

Athens 1.2.15-18)

Clearly there are two distinct discourses operating here: the one an aristocratic open-handedness that takes pleasure in giving, and that can reverse the process of gift-giving: "more welcome are ye to my fortunes | Than my fortunes to me" (1.2.19-20); to this extent Timon's affections are extended to his community of "friends" in what is intended to be a reciprocal a manner, suggested by Montaigne's comment that "if a man urge me to tell whereof I loved him, I feele it cannot be expressed, but by answering; Because it was he, because it was my selfe" (Montaigne 1965, 1.201). But this can also lead to an alternative negative implication as evidenced in Montaigne's 
repetition of Aristotle's sentiment: "Oh you my friends, there is no perfect friend" that exposes the possibility of a self-deception that lies at the heart of what began as a reciprocity (Montaigne 1965, 1.203). What binds the community together is, as Aristotle observed, the link between "friendship" and "justice," because, he says, "in every community there is supposed to be some kind of justice and also some friendly feeling." And he goes on to suggest that "it is natural that the claims of justice should increase with the intensity of friendship, since both involve the same persons and have an equal extension" (Aristotle 1977, 273). In Shakespeare's play the opposing discourse is that of an urban commerce or, in Aristotle's terms, "utility" where friendship is "impermanent" and non-reciprocal once circumstances change. Only the liberal Timon, who is, in a sense, out of time, begins by behaving in the spirit of true "friendship" from which he clearly derives "pleasure." Timon's final withdrawal from community coincides with his loss of "pleasure" in his fellow man, and a death that is equated with an irreversible and extreme misanthropy. Money may make the world go round, but divested of an accompanying moral and ethical social context it becomes a terminally destructive force.

\section{References}

Aristotle. 1977. Ethics. Translated by J.A.K. Thompson. Harmondsworth: Penguin.

— 1992. The Politics. Translated by T.A.Sinclair. Harmondsworth: Penguin.

Bourdieu, Pierre. 1987. Outline of a Theory of Practice. Translated by Richard Nice. Cambridge: Cambridge University Press.

Bullough, Geoffrey, ed. 1977. The Narrative and Dramatic Sources of Shakespeare. 8 vols. London: Routledge.

Copernicus, Nicholas. 1985. Minor Works. Translated by Edward Rosen. London: Macmillan.

Crombie, A. C. 1969. Augustine to Galileo. 2 vols. Harmondsworth: Penguin.

Dawson, Anthony, and Gretchen Minton, eds. 2008. Timon of Athens. London: Arden Shakespeare.

Derrida, Jacques. 1997. The Politics of Friendship. Translated by George Collins. London: Verso. 
Drakakis, John. 2010. Introduction to William Shakespeare. The Merchant of Venice. Edited by John Drakakis. London: Arden Shakespeare.

Goux, Jean-Joseph. 1990. Symbolic Economies after Marx and Freud. Translated by Jennifer Curtis Gage. New York: Cornell University Press.

The Holy Bible (London: Christopher Barker, 1595).

Laslett, Peter. 1983. The World We Have Lost -Further Explored. London: Methuen.

Lupton, Thomas. 1969. A Moral and Pitiful Comedy Entitled All for Money. In English Morality Plays and Moral Interludes, edited by E.T. Schell and J. D. Schuchter. New York: Holt, Rinehart, and Winston.

Marx, Karl. 1981 (1867). Capital. Vol. 3. Translated by David Fernbach. Harmondsworth: Penguin.

Montaigne, Michel de. 1965. Essays. 3 vols. Translated by John Florio. London: Dent.

Oresme, Nicholas. 1956. The De Moneta and English Mint Documents. Translated by Charles Johnson. London: Nelson.

Ovid. 1965. The Metamorphoses: The Arthur Golding Translation, 1567. Translated by John Frederick Nimms. London: Collier-Macmillan.

Shell, Marc. 1982. Money, Language and Thought. Baltimore and London: Johns Hopkins University Press.

Vilar, Pierre. 1976. A History of Gold and Money, 1450-1920. Translated by Judith White. London: NLB.

Wallerstein, Immanuel. 1974. The Modern World System I: Capitalist Agriculture and the Origins of the European World Economy in the Sixteenth Century. San Diego and London: Academic Press.

How to cite this article:

Drakakis, John. "Money makes the world go round: Shakespeare, commerce and community." SEDERI 26 (2016): 7-29.

Author's contact: john.drakakis@stir.ac.uk

Postal address: Faculty of Arts and Humanities - University of Stirling - Stirling FK9 4 LA - Great Britain

Submission: 25/05/2015

Acceptance: 29/01/2016 